\title{
Dr. Gouri Shankar Bhattacharyya, MD, PhD, FRCP [October 31, 1958-May 1, 2021] : A Tribute!!
}

\author{
Hemant Malhotra ${ }^{1}$ \\ ${ }^{1}$ Department of Medical Oncology, Mahatma Gandhi Medical \\ College, Jaipur, Rajasthan, India
}

Ind J Med Paediatr Oncol 2021;42:135-136.

It has been several weeks since we spoke! In usual times, he would call me and yell and say "Why haven't you talked to me for a whole week?" But it is not usual times; it is highly unusual, tragic, and terrible times and his passing away has brought the horrors of pandemic right into our backyard! He tested positive on April 24, hospitalized on April 26, put on ventilator on April 27, and died at 12.35 am on May 1, 2021. Incidentally, May 1 is Shilpi's (his wife) birthday.

GS was more than my best friend. He was my brother, my soulmate, my alter-ego, and my trouble shooter; he was one of the individuals closest to me on this planet. "GS Uncle" to my two sons and "best boyfriend" to Bharti, my wife; he attended every single function in my family. He attended my younger son's wedding (the above picture) and my father's 90th birthday; he was there with me during my mom's illness and then her death-he was there by my side in my times of joy and sorrow-he was more than family to me!

I consider myself lucky to have met and spent 2 days with him during the first weekend of April 2021 at a meeting in Delhi-both of us had decided to attend the meeting in-person and get together after not being able to see each other for more than a year. How I cherish those 2 wonderful days spent together - the joy cannot be expressed in words!

GS to most of us and Gouri dada to some, he was a compassionate and caring human being. He was an oncologist par excellence; he was out of the box and a brilliant thinker; he touched and illuminated so many lives-both professionals and patients. He was a mentor, friend, philosopher, and guide, sometimes all rolled into one, to so many of us. Most of us will miss his sage and scientific advice regarding a difficult or an important patient; I will also miss his yell: "Hemu"across a room/conference hall and his tight hug and hard, sometimes painful, back thumps when we met after a few
Address for correspondence Hemant Malhotra, MD, FRCP (London), FRCP (Edinburgh), FACP (USA), ECMO, MNAMS, FUICC, FICP, FIMSA, C-70, Ram Marg, Tilak Nagar, Jaipur, Rajasthan, 302004, India (e-mail: drmalhotrahemant@gmail.com).

days! I will remember, miss, and cherish the memories of the countless evenings we had together, just the two of us, the many conferences we attended, and the several holidays we enjoyed together.

I had the opportunity to study his current bio-data-was in the process of nominating him for the Fellowship of the Royal College of Physicians of Edinburgh. Even after knowing him for more than 30 years, I was astounded by his many achievements.

The son of a highly regarded army officer, he did his schooling and college from several institutions across the country, MBBS from Calcutta and finally MD in Medicine from the prestigious Tropical School of Medicine, Calcutta. After a brief but impressive stint as a scientist with the Indian Council of Medical Research (ICMR) where he was the blue-eyed boy of the Director General, he moved to Glasgow, England, for further studies in hematology and oncology and his $\mathrm{PhD}$ thereof.

The urge to serve and work for the people of his motherland brought him back to Calcutta in 1997 where he set up a clinic and started working in the field of hematology and oncology.

During his illustrious career of more than 40 years, he made a name for himself, both, nationally and internationally. It will not be an exaggeration to say that he was instrumental and responsible for taking Indian oncology to the world. His in-depth understanding of pharmacology and the basics of his subject were his strengths. His contributions to the Breast International Group (BIG), the European Society for Medical Oncology (ESMO), the International Society for Geriatric Oncology (SIOG), the International Society for Pain \& Palliative Care, International Society for Pharmacoeconomics and Outcomes Research (ISPOR), International Association
DOI https://doi.org/ 10.1055/s-0041-1732816 ISSN 0971-5851
C 2021. Indian Society of Medical and Paediatric Oncology. This is an open access article published by Thieme under the terms of the Creative Commons Attribution-NonDerivative-NonCommercial-License, permitting copying and reproduction so long as the original work is given appropriate credit. Contents may not be used for commercial purposes, or adapted, remixed, transformed or built upon. (https://creativecommons.org/licenses/by-nc-nd/4.0/).

Thieme Medical and Scientific Publishers Private Ltd. A-12, Second Floor, Sector -2, NOIDA -201301, India 
for the Study of Pain (IASP), and American College of Clinical Pharmacology (ACCP) are well recognized and appreciated.

On the national front, he served as the President of the Indian Society of Medical \& Pediatric Oncology (ISMPO), and was one of the founder members of the Indian Cooperative Oncology Network (ICON). He was on the executive committee of almost all nationally relevant hematology and oncology societies. He was on several government of India and national guidelines' committees and contributed to Indian oncology big time.

Born of a brilliant and inquisitive mind, his in-depth knowledge of the subject made him the ideal candidate for conducting innovative clinical research. He was one of the early pioneers in the field in India and had multiple trials under his belt, both national and international, while most of us were just entering the field. He was a part of several international pivotal clinical phase III trials in oncology. His brilliant work on mechanistic target of rapamycin inhibitor, sirolimus, in hormone-receptor positive breast cancer was a late-breaking abstract in the 34th ESMO Congress in Berlin way back in 2009. Since the past few years, he was working on developing a novel combination (which he called VT-122-a simple and inexpensive combination of celecoxib and propranolol), which could lower the toxicity of some targeted therapies and chemotherapy. He had managed to not only patent this compound but also seek and obtain U.S. Food and Drug Administration Orphan Drug designation for the same.

He had a particular passion for palliative care, pain relief, and hospice care and, in association with the IASP, of which he was an international contributing member, he made several sentinel contributions to the field. He was also an active member and on the executive committee of the International Association for Hospice \& Palliative Care (IAHPC).

Geriatric oncology was one more major focus area for GS as he realized the importance of developing the same in India. He was on the board of the International Society of Geriatric Oncology (SIOG) and did bring to fruition several collaborations and initiatives and sowed the seed of the specialty in our country.

GS was particularly passionate about the cost of treatment and pharmacoeconomics in oncology especially with reference to newer, very expensive molecules used rampantly due to industry pressure with minimal benefit. He was a fan of the ESMO Magnitude of Clinical Benefit Scale and, under the auspices of the International Society of Pharmaco-economic Research, of which he was a committee member, worked on development and implementation of several cost-effective modules in India. Most of us have witnessed and will remember his forceful and insightful comments during conferences especially when discussing cost-benefit ratio for the expensive medicines. He was indeed forthright and fearless in his beliefs and convictions and had no qualms in speaking them out!

His academic bent of mind can be judged by his active membership of so many international societies, his presence on several advisory boards of international, and national journals and the fact that he was a much sought-after referee for articles in many international and national journals. He had to his credit more than 200 peer-reviewed publications including several book chapters. His most recent invited editorial, of which we were co-authors, was in the prestigious Journal of Clinical Oncology. He was an invited speaker at several ESMO, ESMO Asia, and American Society of Clinical Oncology (ASCO) conferences.

On a personal note, he was an invaluable friend, always available for help and guidance, clear-hearted, and straightforward. He would not hesitate to call a spade a spade. Every half hour spent with him meant that you would get some new insight and fresh perspective in matters, both, academic and nonacademic. He was very well read, had an encyclopedia-like mind, and elephant-like memory. He would constantly amaze you with the depth and variety of his knowledge ranging from music to poetry to arts to perfumes to literature-you name it!

He is survived by his charming wife, Shilpi; we pray to the Almighty to grant her the strength to bear this huge loss and the serenity to move on with her life!

Our tribute to him will be to continue to inculcate his fervor in pursuit of science.

GS, you were an exceptional individual, the likes of which walk the face of this earth, rarely! It was our pleasure and privilege to briefly share this journey with you and we are all the more enriched by the experience!

Rest in peace, wherever you are! And continue to guide us with your unseen self but ever-present spirit!

We will always remember you and the time spent with you!

"Though we're left in darkness, we know the 'Sun' has not died, for it is shining brightly on the world's other side"

[He wrote and sent me these lines on the death of my mother!!]

\section{Conflict of Interest}

None declared. 